\title{
Reduction of liberalism in Lithuanian media policy
}

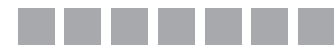

Deimantas Jastramskis

VILNIUS UNIVERSITY, LITHUANIA

DOI: 10.19195/1899-5101.9.2(17).2

\begin{abstract}
Lithuanian governments had been conducting liberal economic policies regarding media subjects for almost two decades, till the end of 2008. However, the economic crisis in 2008 influenced the Lithuanian government to apply the measures of fiscal consolidation: in similar fashion, liberal media policy was adjusted with the state gaining more power. The aim of this article is to analyze Lithuanian media policy decisions and their effects on media sectors, organizations and workers during the period of the economic crisis and since then. The article claims that essentially reduced liberalization of taxation, slightly reduced commercialization of the national media environment and reinforced overly bureaucratic system of media regulation resulted in a lesser degree of liberalism in the Lithuanian media policy from the end of 2008 to 2015.
\end{abstract}

KEYWORDS: media policy, liberalism, state, crisis, regulation, marketization.

\section{ㅁㅁㅁㅁㅁㅁㅁㅁㅁ}

\section{INTRODUCTION}

After the creation of the Reform Movement of Lithuania, Sajūdis, in 1988 essential reforms of the Lithuanian one-party political system created starting conditions for the liberation of Lithuanian media from the clutches of the Communist party and for the formation of a free media market. The number of newspapers had grown more than twice in 1988-1989, if compared to 1987 (Burneikiené, 2005). A major part of the newly established press were outlets of Sajüdis or other new political, non-governmental organizations. Besides, the leading daily in the Lithuanian market - the daily of Young Communist League of Lithuania Komjaunimo tiesa - was privatized at the end of 1989 and since 1990 has been published as Lietuvos rytas. Moreover, an era of inner pluralism had started in the only Lithuanian broadcaster at that time - Lithuanian television and radio owned by the state. Hereby the trend of liberalization in the Lithuanian media took place even before the official restoration of independence of Lithuania in 1990.

Implementation of major economic reforms started in 1991, when the collapse of the USSR and restoration of Lithuanian independence attained broad international recognition. The plan of the economic reform for Lithuania and the other 
post-communist countries of Central and Eastern Europe was prepared in collaboration with the World Bank and the International Monetary Fund. The liberalization of prices and trade altogether with the privatisation were the cornerstone elements of this plan (Starkevičiūtè, 2000). Lithuania and other Baltic countries (Estonia and Latvia) made clear liberal policy choices and:

[...] have stood out among the European transition countries as radical pro-market reformers. (Kattel \& Raudla, 2013, p. 427)

The trend of liberalism was strong in Lithuanian media policy. Alliance of the Lithuanian governments and concentrated media business (formed in the poorlyregulated privatization process) maintained the liberal trend of media policy for almost two decades, till the end of 2008. However, a deep recession in the Lithuanian economy - the country's gross domestic product fell by $14.8 \%$ and the Lithuanian economy was hardest hit in the EU in 2009 (Eurostat, 2015) prompted the 15th Lithuanian Government (the term of office 2008-2012) to apply the measures of fiscal consolidation and in similar fashion to shift the liberal media policy towards the state gaining more power.

This article aims to analyze Lithuanian media policy decisions and its effects on media sectors, organizations and workers. Changes regarding the liberalization, marketization, commercialization and deregulation of media in the period of economic crisis and after it (from the end of 2008 to 2015) are also analyzed. Methodologically, the study is based on the document analysis of the relevant laws, resolutions regarding media subjects, annual reports of state institutions, regulatory/ co-regulatory authorities and the data of media monitoring companies, non-governmental organizations and media organizations.

\section{DEVELOPMENT OF LIBERAL MEDIA POLICY}

Democratization and liberalization of the Lithuanian media were accompanied by the rapid privatization of old and new media outlets and organizations in the 1990s. The privatization of the property of Lithuanian national and local media companies took place in the period 1991-1995, in the so-called voucher privatization process. Employees of these companies were granted priority to purchase the shares of the media companies. In 1996 the state had been eliminated from the ownership of media companies almost completely (with the exception of the National Radio and Television of Lithuania), when the Republic of Lithuania Law on the Provision of Information to the Public (1996) was adopted by the Lithuanian Parliament.

Deregulation or reduction/removal of the state from the regulation of media industries (Freedman, 2008) was a spontaneous process in 1990s Lithuania, mostly fueled by aspirations to get rid of the communist legacy of public sphere control. However, the need to escape from the total state control of media and no introduction of special restrictions on the horizontal, cross-media and diagonal media con- 
centration led to another extreme situation: a considerable part of media businesses became the property of large private national and foreign corporations.

On the other hand, at least some power in the media remained in the hands of Lithuanian state authorities. Democratically-elected politicians did not want to surrender their direct influence on the National Radio and Television of Lithuania (LRT). The LRT board and director general had been appointed by the Lithuanian Parliament in 1990-1996. Since 1996, these appointments are carried out by the LRT Council which is formed from the representatives of politicians and nongovernmental organizations. Besides, Lithuanian policy makers constructed an overly bureaucratic system of media regulation. This system combines three media regulation institutions on a statutory basis: the Office of the Inspector of Journalist Ethics, the Radio and Television Commission of Lithuania and the Ethics Commission of Journalists and Publishers (the Ethics Commission of Provision of Information to the Public since 2015).

Despite the general trend of marketization which "refers to attempts in all media environments to secure the highest ratings and extract the greatest profits" (Freedman, 2008, p. 52) in the Lithuanian media system, two other important components of the economic policy regarding media subjects (direct subsidies) should be mentioned: state budget allocations for the Press, Radio and Television Support Foundation (PRTSF) and the LRT. The PRTSF activity in the funding of cultural, educational and media literacy projects (conducted by various media organizations) creates a little counterweight to the marketization of the media field. Only those media organizations that have not infringed on the established legal and ethical norms during the last calendar year (prior to the allocation of support to the relevant projects) are eligible for state support. The amount of state budget allocations for the PRTSF accounted for a modest $1.06-1.35 \%$ of the Lithuanian advertising market during 2002-2008 (Jastramskis, 2013; TNS LT, 2014a) and did not have the potential to distort the competition relations in the media market. Funding of the LRT from the state budget has been insufficient and consequently the LRT has been participating in the advertising market.

A very liberal policy approach had been framed on the taxation of print goods and services and especially on the taxation of the labor force in the media market. Lithuanian publishers of newspapers and magazines had privileges of value-added $\operatorname{tax}$ (VAT) for the supply of the periodical press. Zero rates of VAT had been applied for the supply of newspapers and magazines during 1991-2002. Moreover, exemptions of the zero rates of VAT had been extended for the service of publishing and printing of the periodical press in the period 1994-2002 (also, for the supply of newsprint during 1997-2002). However, the exemptions of the zero rates of VAT for the supply and services regarding media activities expired when Lithuania had started intensive preparations to join the European Union (EU) and had begun harmonizing the country's laws with EU legislation. In this case - with the EU Council Directive 77/388/EEB (Sixth VAT Directive). The reduced rate of 5\% VAT 
has been applied for the supply of newspapers and magazines (also books) in the period 2003-2008 (Republic of Lithuania Law on Value Added Tax, 2002; Jastramskis, 2013).

The reorientation of Lithuania from the East to the West in the 1990s and the creation of a liberal employment regime formed a labor sector that was mainly constituted by predominantly private employment of low-wage, unprotected and "flexible" labour (Juska \& Woolfson, 2015, p. 239). The liberal peculiarity of the labor in the Lithuanian media sector was that all media organizations had the advantage to employ creative workers while paying very low social insurance contributions. Income under the author's agreements had not been subject to social insurance contributions at all during the period 1990-2008. Therefore media workers (journalists, editors etc.) had been recruited using a dual scheme: under employment contracts with being paid minimum salaries (and minimum social insurance contributions) and/or under the author's agreements (often under a verbal agreement only) without any social insurance contributions. On the one hand, such a remuneration system of salaries and honorariums had been generating more income for media companies and workers. On the other hand, low social insurance contributions had contributed to unsatisfactory social security for media workers.

\section{DE-LIBERALIZATION OF TAXATION}

The global financial crisis started in the USA in 2007; its effects reached Lithuania at the end of 2008. The necessity to react quickly to the rapidly worsening economic situation and projected decline of budget revenues dominated the political agenda of the newly formed right-centre coalition (Nakrošis et al., 2015, p. 7), as early as the new government was sworn in December 2008. As we can see in the Programme of the Government of the Republic of Lithuania (2008), there was no specific obligation to change the taxation of media subjects. However, in section "II. Immediate taxation measures" these measures were delineated: cancelation of reduced VAT and reformation of the social and health insurance system during the period 2009-2010, by including persons still not involved in them.

According to Meier and Trappel (2015), even under the neoliberal paradigm three different types of media policy options are principally available in times of crisis: no government action (state as observer), government undertakes some positive action and monitors its measures (state as moderator), government actively interferes (state as crisis manager). In response to the economic crisis of 2008, the government of Lithuania undertook measures of restrictive fiscal policy: a decrease in state expenditures and at the same time increase of taxes, in order to stabilize state finances (Davulis, 2012). The reform of tax and social insurance contributions was implemented in quite a short span of time and had a significant impact on the media industry. The government chose to be an active crisis manager and, essen- 
tially, it was a radical shift from the previous liberal economic policy regarding media subjects.

The Lithuanian government in 2009 took the obligation to impose social insurance contributions on the incomes of journalists (and other creative workers) who work under the author's agreements. The state acted in a manner of social responsibility and showed its power to the media business. Although this act formally strengthened the social security of media workers, the following increase in social insurance contributions for the author's agreements by 40 percentage points (until 2011) in turn reduced the income of media companies and media workers. Such increased taxation and a direct consequence of the economic crisis (mainly the shrinkage of the advertising market) had a significant impact on the number of employees in the media.

As we can see in Figure 1, the number of employees in Lithuanian media enterprises fell by 2218 (i.e. 33\%) in the period 2008-2012. The unemployment rate in Lithuania fell by $7.6 \%$ in the same period (Statistics Lithuania, 2015a). During the period 2009-2012, the largest decrease (50.3\%) in the number of employees was observed in the television industry, when compared with 2008. The newspapers industry and journals lost $33.8 \%$ of employees during the same period. However, the number of employees in the web portals industry was higher by $33.3 \%$ in 2012 than in 2008. The growing industry of web portals slowed down only in 2009 when the number of employees fell by 1.3\%, if compared with 2008 (Figure 2).

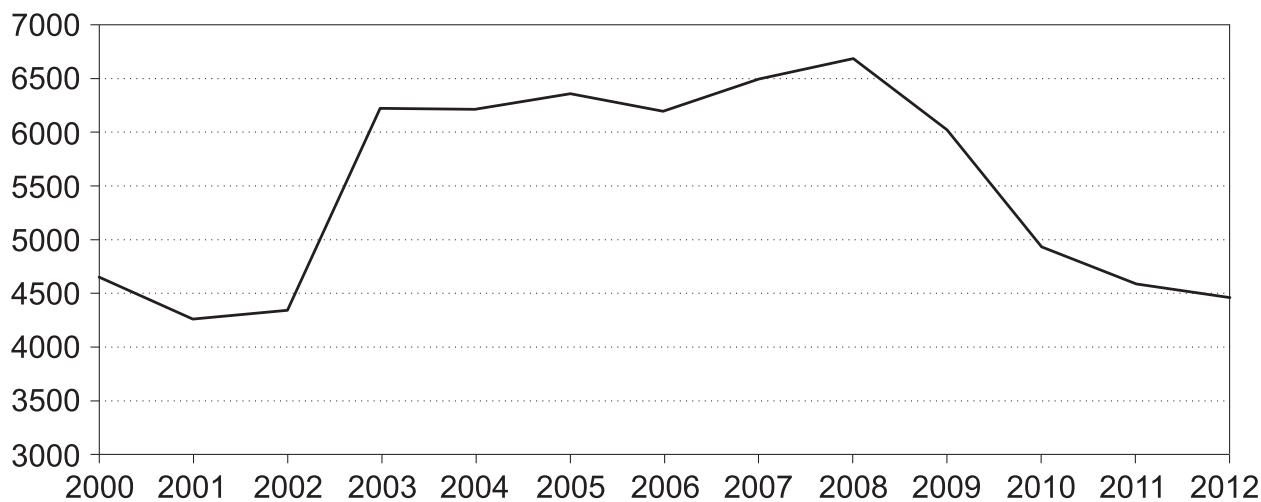

Publishing of newspapers, journals; radio broadcasting; TV programming and broadcasting; TV, motion picture, video programme production; web portals

Figure 1. Number of employees in media enterprises in 2000-2012

Source: Statistics Lithuania (2015a).

The sum of salaries in the newspaper and journal publishing industry fell dramatically (39\%) in the period 2008-2012: from 30680 to 18652 thousand EUR. The sum of salaries in the broadcast television industry fell further (59\%) in 2010 (com- 


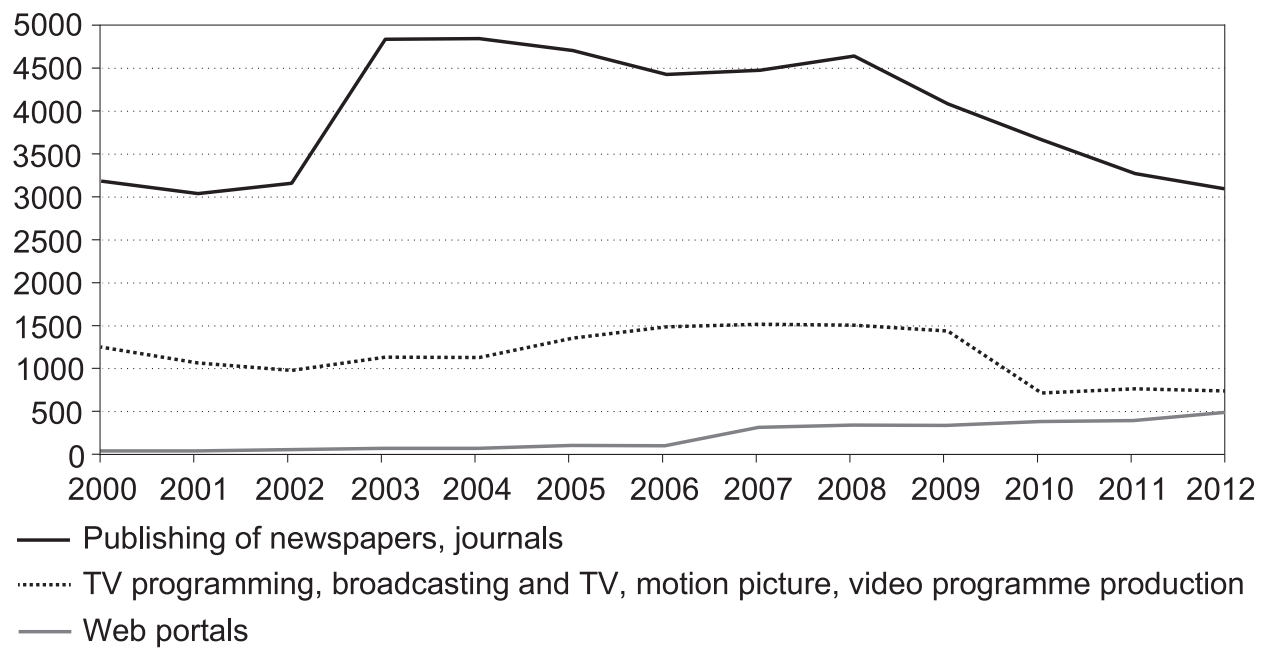

Figure 2. Number of employees in publishing, television and web portals enterprises in 2000-2012

Source: Statistics Lithuania (2015a).

pared with 2009): from 13766 to 5649 thousand EUR but were higher in the following two years (2011-2012). However, we can see a different trend in the industry of web portals: although salaries fell quite dramatically in 2009 (31\%), three years later there was observed a trend of rapid increase (from 1910 to 3946 thousand EUR) (Statistics Lithuania, 2015a; Figure 3).

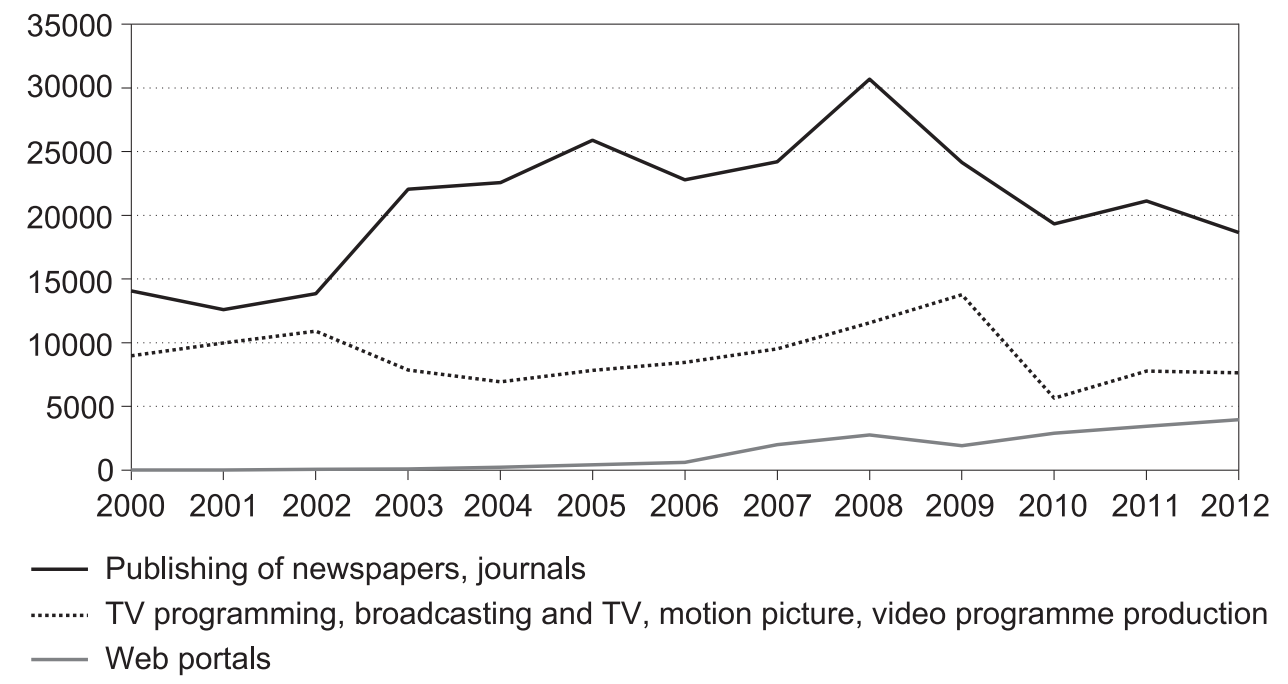

Figure 3. Salaries in media enterprises in 2000-2012 (EUR thousands)

Source: Statistics Lithuania (2015a). 
Due to the reform of social insurance contributions and because of the economic crisis, journalists' incomes in Lithuania decreased dramatically. The average gross monthly salary of journalists (487 EUR) was $15.5 \%$ less than the average gross monthly salary in the whole Lithuanian economy in 2010 (576 EUR) (Statistics Lithuania, 2015b; see Figure 4). Besides, journalism in Lithuania was one of the five professions where employees lost the largest share of their remuneration (25\%) in the period 2007-2012 (Veidas.lt, 2012). A similar trend is observed in 2014: the average gross monthly salary of journalists (602 EUR) was $11.1 \%$ less than the average gross monthly salary in the whole Lithuanian economy (677 EUR) (The State Social Insurance Fund Board, 2015) (Figure 4).

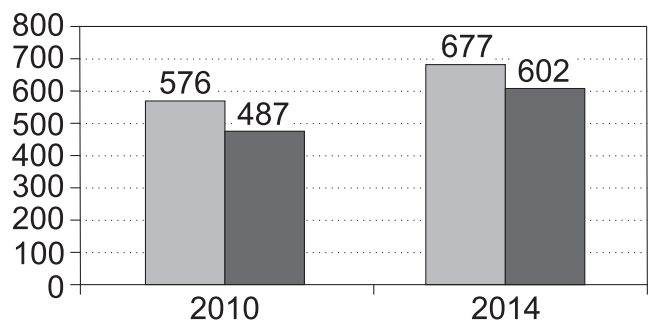

$\square$ Average gross monthly salary of the whole Lithuanian economy

a Average gross monthly salary of journalists

Figure 4. Average gross monthly salary in Lithuania in 2010 and 2014 (in EUR)

Source: Statistics Lithuania (2015b), the State Social Insurance Fund Board (2015).

It is also important to emphasize that the aforementioned social security reform had certain side effects: many media workers were forced to work as freelancers on the basis of certificates issued by the State Tax Inspectorate. Such a status of selfemployed persons provides limited social security. Media workers engaged in individual activities (freelancers) are covered on a compulsory basis by the pension, maternity (paternity) and health social insurances. However, they are not covered by the social insurances for sickness, unemployment, occupational accidents and occupational diseases: these are granted only for media workers employed under labor contracts and/or work under the author's agreements (The Republic of Lithuania Ministry of Social Security and Labour, 2015). Moreover, some media employers employed a practice of paying part of the remunerations for journalists illegally, i.e. without paying required taxes (Elta, Lrt.lt, 2012) and consequently not providing any social insurance contributions.

Working without a labor contract and/or an author's agreement, i.e. working on a basis of certificate is most widespread in the television industry. According to the State Tax Inspectorate (2015), the number of persons working on the basis of certificate engaged in motion picture, video and television programme activities in- 
creased as much as 18.4 times in the period 2010-2014 (compared with 2009): from 42 to 774 . The number of persons working on a basis of certificate engaged in photographic activities increased 5.1 times in the same period: from 118 to 597. Also, it is worth mentioning that increasing numbers of such freelancers have also been observed in the media organizations of the web portals industry (Figure 5).

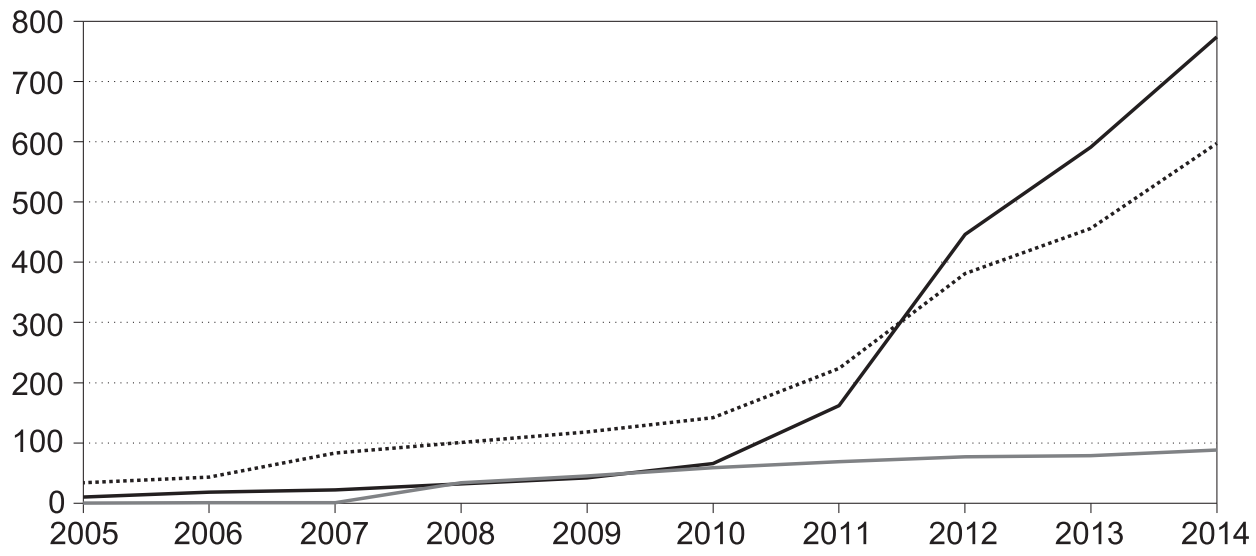

- Motion picture, video and television programme production activities

.......... Photographic activities

Web portals

Figure 5. Number of persons working on the basis of certificates (freelancers) issued by the State Tax Inspectorate in 2005-2014

Source: the State Tax Inspectorate under the Ministry of Finance of the Republic of Lithuania (2015).

Introduction of social security reform for media organizations in the period 2009-2012 was accompanied by removal of VAT privileges for the supply of periodical press (VAT increased from 5\% to 21\%). Only books and non-periodical informational publications remained subject to the $9 \%$ rate of VAT. This media policy act weakened the financial capacity of Lithuanian newspapers and magazine publishers, alongside the economic crisis and the growing competition with global players in the local national markets. For example, the incomes of Google in Europe grew every year in the period 2007-2013 and increased from 12 to 45 billion of EUR (Saura \& Papathanassopuolos, 2015). On the contrary, during the period 2009-2012 revenues from advertising among Lithuanian media companies (television, radio, periodical press and internet) decreased by $37.4 \%$. Publishers of newspapers and magazines lost more than a half of their revenue (51.7\%) from advertising, subscriptions and press sales during the same period (Statistics Lithuania, 2015a; TNS LT, 2014a). The VAT privilege to the periodical press has been reinstalled since 2013, but it is now fixed at the level of $9 \%$. 


\section{POLICY REGARDING DIRECT SUBSIDIES}

Partially compensating for the removal of VAT privileges and negative effects of reform on social insurance contributions, the state has increased support for media organizations through the Press, Radio and Television Support Foundation (PRTSF) since 2009. However, increased direct state subsidies were relatively small if compared with the dramatically decreased revenues of media companies from advertising and subscriptions (imposed social insurance contributions also have to be considered). In 2009, when state support through the PRTSF had the largest increase and had been highest during the period 1997-2013 (3.4 million euros), rise of this support (1.7 million euros) was equal only to $2.9 \%$ of the losses of media organizations (television, radio, periodical press and web portals) in the advertising market (Jastramskis, 2013; TNS LT, 2014a). Obviously, this amount of state support could not compensate for the losses of media companies.

In this situation, when advertising of goods and services of business companies dramatically decreased and the subsidies through the PRTSF did not play a significance role, Lithuanian media became more dependent on the state or other influential political actors regarding funding. Firstly, Lithuanian state and municipal institutions were one of the largest advertising clients in the periodical press in the period 2009-2010 (TNS LT, 2010; TNS LT, 2011). Secondly, due to the increase of incomes from advertising, media organizations were largely focused on advertising related to the Lithuanian municipal elections in 2011 (TNS LT, 2012). Thirdly, data provided by The Public Procurement Office shows the value of public procurements devoted to publicity services as 31.4 million euros in 2012 and the first half of 2013. A total number of 90 organizations carried out the procurement of publicity services in this period. The value of the publicity services outsourced by the largest purchaser - The Ministry of Agriculture of the Republic of Lithuania - totals 5.1 million euros (The Public Procurement Office, 2014; Jastramskis, 2015). There was a significant increase in the advertising budgets of state institutions and EU-sponsored projects in 2013. Finally, the data from the survey of the major media planning agencies, advertisers, media owners and CEOs (conducted by TNS LT in February 2014) revealed optimistic forecasts for 2014: besides the recovering economy, President and EU Parliament elections, introduction of the euro and other state-sponsored projects were expected to attract more advertising funds in 2014 (TNS LT, 2014b).

Another important aspect in the system of direct subsidies for media companies is the funding of the public service broadcaster of Lithuania. The National Radio and Television of Lithuania is a public non-profit organization that belongs to the state by the right of ownership. The Law on the Provision of Information to the Public (1996) stipulated that the LRT shall be financed by allocations from the state budget, subscription charge, commercial income and charitable contributions. Also this Law stipulated that with the increase of the LRT income from the subscription 
charge, the financing of the LRT from the state budget shall be decreased accordingly. However, the financing of the LRT from the subscription charge was not implemented altogether. The obligation regarding the introduction of the subscription charge was removed from the Law in 2005.

The LRT has been funded from the State budget and commercial revenues (mostly advertising) for more than two decades. Funding from the state budget was always higher than commercial revenues. Besides, funding from the state budget has been changing each year. It depended on the political will of the Lithuanian Parliament. As we can see in Figure 6, the share of state funding of the LRT decreased gradually in the period 2005-2008 and hit the lowest mark in 2007 and 2008 (accordingly 59.4\% and 58.6\%) when the growth of Lithuanian economy guaranteed rapid development of the advertising market.

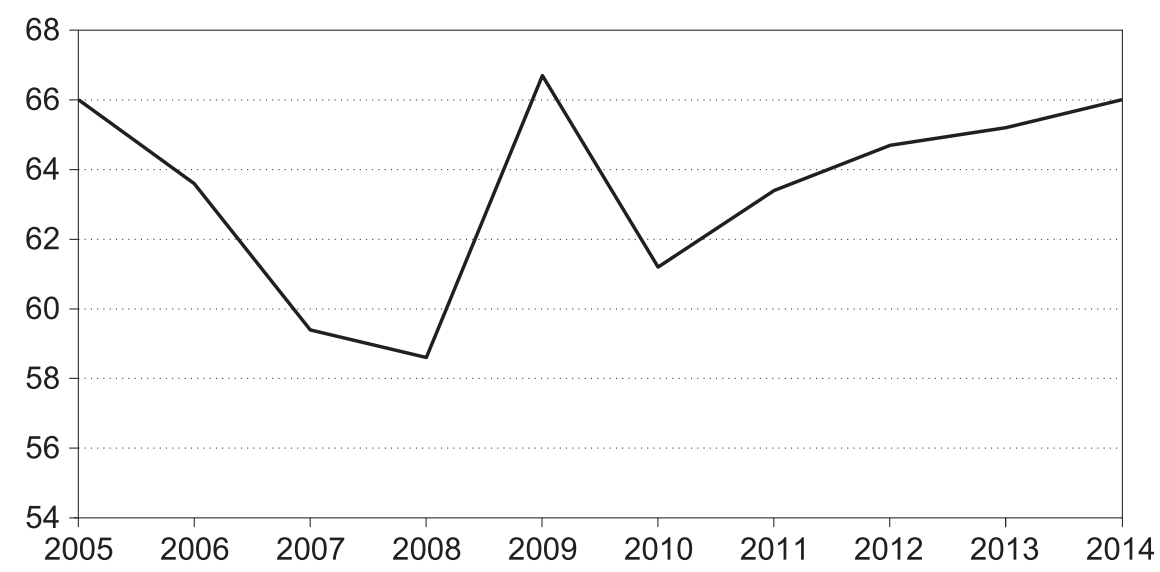

Figure 6. State funding in the LRT budget in 2005-2014 (in \%)

Sources: the author's calculations; Republic of Lithuania Laws on Approval of the Financial Indicators of the State Budget and Municipal Budgets, 2004-2014; Annual reports 2005-2014 of the Lithuanian National Radio and Television.

It is worth accentuating that LRT is one of the most poorly-financed public service broadcasters in the European Union. Data from the European Audiovisual Observatory shows that Lithuania occupied last place according to the average expenditure by one resident for the financing of the public audiovisual sector in 2006 (Lange, 2008). Despite such a situation, the Lithuanian Parliament cut off almost one-third (31.3\%) of state funding for the LRT at the peak of the economic crisis (2009-2010) if compared to 2008. The total budget (adding the commercial income) of the LRT decreased by $34.3 \%$ in this two-year period (Figure 7). Therefore data from the European Broadcasting Union (2012) indicates that Lithuanian expenditure allocated for public service broadcasting in 2010 accounted for the smallest percentage of GDP in the European Union. Since 2011, revenue (state funding and commercial income) of the LRT rose consistently each year until 2014. 
However, it did not achieve the level of 2007 and 2008. Besides, this did not change the position of Lithuania among EU member states. Lithuania remained the last EU member state according to PSM funding as a percentage of GDP in 2013 0.07\% (EU Average was 0.20\%) (European Broadcasting Union, 2014).

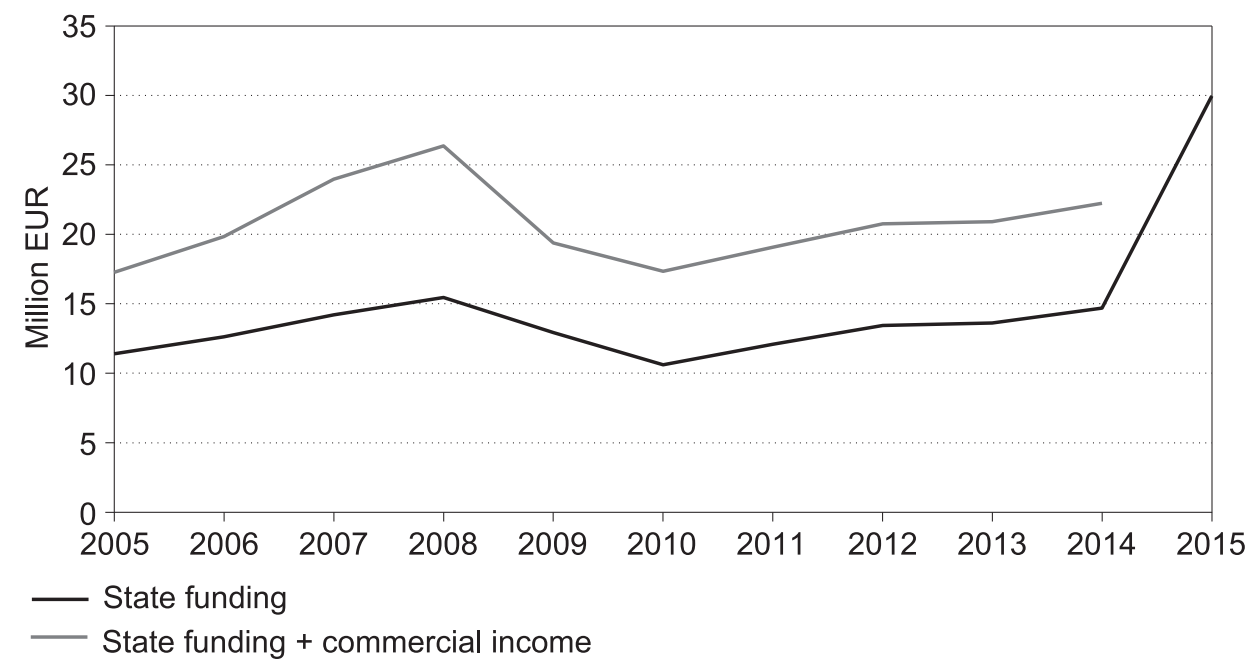

Figure 7. The LRT budget (state funding and commercial income) in the period 2005-2014, and the LRT state funding obligation in 2015 (in EURO)

Sources: Republic of Lithuania Laws on Approval of the Financial Indicators of the State Budget and Municipal Budgets, 2004-2014; Annual reports 2005-2014 of the Lithuanian National Radio and Television.

The low level of funding of the LRT from the state budget in the time of the economic crisis had a negative influence for the fulfillment of delegated functions for the LRT and quality of some shows. This fostered the outgoing government to register the law amendment and to initiate more perspective planning of funding of the LRT in the end of 2012 (and in the end of the crisis). Since 2015 funding of the LRT has been related to the revenues of the state and municipalities budgets (1.5\% from income tax and $1.3 \%$ from excise revenues) (Republic of Lithuania Law Amending Article 3 of the Law Amending and Supplementing Articles 6, 7, 15 of the Law on National Radio and Television, 2014). Besides, since 2015 the LRT does not have a right to receive advertising income, except in cases of commercial obligations concerning the broadcasting of international events and promotional announcements of culture, sport and educational events (Republic of Lithuania Law Amending and Supplementing Articles 6, 7, 15 of the Law on National Radio and Television, 2014). However, this prohibition does not apply to the commercial content in the LRT web portal due to the different approaches of policy makers on the regulation of advertising in the internet on the one hand and conventional media on the other. 
The amount of LRT funding planned to allocate from the state budget for 2015 exceeds by more than double the state funding in 2014. Also, this planned figure is $12 \%$ more than the total budget of the LRT in the most successful (in terms of budget size) year, 2008 (Figure 7). However, such a media policy step regarding the funding of public service broadcaster is still not sufficient to take out the LRT from the level of the least financed public service media in the European Union.

\section{SHIFT IN THE MEDIA REGULATION SYSTEM}

Statutory media regulation has dominated against the self-regulation of media in Lithuania since the 1990s. Initially, the newly found Board of Press Control became directly subordinated to the Ministry of the Interior of Lithuania (since 1992 - to the Ministry of Justice). In 1996, the Republic of Lithuania Law on the Provision of Information to the Public (1996) established a media regulatory system comprised of three bodies: the Office of the Inspector of Journalist Ethics (Inspector), the Radio and Television Commission of Lithuania (RTCL) and the Ethics Commission of Journalists and Publishers (ECJP). The Inspector is a state officer and is appointed by (and is accountable to) the Parliament of Lithuania. The activities of the Inspector are funded from the state budget.

The management structures of the media co-regulatory bodies (the RTCL and the ECJP) were changed in the direction of a weakening of the influence of nongovernmental organizations; 9 out of 13 of the RTCL members had been delegated by non-governmental organizations (the other 4 members had been delegated by politicians) in the period 1996-2012. At the same time the chairman and vice-chairman of this commission were elected by its members. However, the influence of non-governmental organizations in the management structure of this regulatory body has decreased since 2013 as a result of the adoption of the Republic of Lithuania Law Amending Article 47 of the Law on the Provision of Information to the Public (2012). There are 6 (out of 11) members of the RTCL delegated by non-governmental organizations and 5 delegated by politicians ( 3 by the Parliament and 2 by the President) currently. However, the most important aspect here is that the chairman and vice-chairman of the RTCL have been appointed by the Parliament since 2013. Representatives of the two largest governing coalition parties, the Labor Party and the Social Democratic Party, were appointed in 2013 and 2015 respectively.

The Ethics Commission of Journalists and Publishers is formed in accordance with the Republic of Lithuania Law on the Provision of Information to the Public (1996). Furthermore, its functions and activities are regulated by this law too. It specifies that the ECJP is not a self-regulatory institution: co-regulation would be a more accurate term to describe its supervision. The ECJP consisted of media organizations' associations, journalists' organizations and other non-governmental organizations' representatives during the period 1997-2014. 
In accordance with the Republic of Lithuania Law Amending Articles 3, 31, 41, 43, 46, 49, 50 and Supplementing by Article 46-1 of the Law on the Provision of Information to the Public (2014), the ECJP (since 2015 - the Ethics Commission of Provision of Information to the Public) is now comprised of 5 representatives from media organizations' associations and 2 from journalists' organizations, i.e. the representatives of the media industry are included. Such elimination of nongovernmental organizations (which are not directly tied with the media industry) shows that the media ethics evaluations became much more dependent on the same players in the media market.

Thus, it could be claimed that in the period 2012-2014 media regulation became more statutory expressed in Lithuania. On the one hand, co-regulation of Lithuanian broadcasting and re-broadcasting sector shifted more closely to the direct regulation of the government. On the other hand, the statutory regulation and corporatist bureaucratization of the supervision of media ethics created an obstacle for the formation of a media self-regulatory system.

\section{CONCLUSIONS}

The imposition of social insurance contributions on the income of media workers that work under the author's agreements and the removal of VAT privilege for the supply of periodical press were all part of the overall fiscal consolidation undertaken by the Lithuanian government in the period of the economic crisis. It was a radical shift from the previous liberal taxation policy regarding media subjects that could be interpreted in two ways: as state acting in the fashion of social responsibility or the testimony of state power to the media business. Consequently, the de-liberalization of taxation reduced the income of the media companies. This has negatively influenced the financial sustainability of media organizations and Lithuanian media became more dependent on the state or other influential political actors for funding.

Moreover, the economic policy decisions aimed at increasing social insurance contributions for the author's agreements had a substantial influence on the decrease of the number of media workers and their earnings in the period of the economic crisis. These decisions also stimulated the increase of the number of persons working on the basis of certificates (freelancers), i.e. a cheaper labor force with limited social security. It must be acknowledged that the somewhat liberal taxation previously was regained at the end of the crisis and VAT privilege to the periodical press has been reinstalled since 2013, but it is now fixed at the level of $9 \%$.

Partially compensating for the removal of VAT privileges and the imposition of social insurance contributions, the state has increased support for media organizations through the Press, Radio and Television Support Foundation since the beginning of the crisis. Even though the increased state subsidies did not essentially cover the dramatically decreased revenues of media companies, the state 
demonstrated consistency supporting cultural media outlets and educational projects in the various media platforms. Some counterweight for the marketization of the media field was maintained.

Insufficient state funding of the Lithuanian public service broadcaster led to the linking of LRT funding with the revenues of the state and municipalities budgets (a percentage from income tax and excise revenues). Such a model of LRT funding reduced the dependency of the public service broadcaster on the political will of the Lithuanian Parliament each year to increase or decrease LRT funding. Moreover, the withdrawal of the LRT from the television and radio advertising market (with the exceptions in the cases of promotional announcements and advertising in the LRT web portal) slightly reduced commercialization of the national media environment.

Regulation of media structures (concentration) both during and after the crisis remained untouchable, i.e. complete deregulation still persists regarding the special restrictions on horizontal, cross-media and diagonal media concentration in Lithuania. However, the introduction of political appointments to the Radio and Television Commission of Lithuania and the statutory framing of the supervision of media ethics shows an increase of state influence on the regulation of media content.

To sum up, three main trends in Lithuanian media policy are of foremost importance since 2008: 1) essentially reduced liberalization of taxation (the imposition of social insurance contributions on the income of media workers that work under the author's agreements, removal of VAT privilege for the supply of periodical press); 2) slightly reduced commercialization (the LRT withdrew from the television and radio advertising market and has been mostly funded from the state budget); and 3) reinforced the overly bureaucratic system of media regulation (the influence of non-governmental organizations was reduced in the management structures of the two media co-regulatory institutions). All of these aspects contributed to the reduction of liberalism in Lithuanian media policy and the consolidation of state influence on the media activities in the period of the economic crisis and after it (from the end of 2008 to 2015).

\section{REFERENCES}

Annual reports 2005-2014 of the Lithuanian National Radio and Television. Retrieved October 11, 2015 from http://www.lrt.lt/apie-lrt/lrt-taryba/dokumentai.

Burneikienė, G. (2005). Lietuvių periodinès spaudos sistemos raidos ypatumai (1988-2003) [Peculiarities of the Development of the Lithuanian System of Periodical Press (1988-2003)]. Knygotyra, 45, pp. 142-154.

Davulis, G. (2012). Global crisis and economic processes in Lithuania and other Baltic countries. Business Systems and Economics, 2(1). Retrieved October 4, 2015 from http://www.mruni.eu/ upload/iblock/383/010_davulis.pdf.

Elta, Lrt.lt. (2012). Premjeras sveikina žurnalistus, prabilusius apie "vokelius" "balsas.lt" leidinių grupeje [Prime minister congratulates journalists, who speak about "envelopes" in the balsas.lt 
publishing group]. Lrt.lt, 2012-10-24. Retrieved October 16, 2015 from http://www.lrt.lt/naujienos/ekonomika/4/6611/premjeras_sveikina_zurnalistus_prabilusius_apie_vokelius_balsas. lt_leidiniu_grupeje.

European Broadcasting Union. (2012). EBU viewpoint. PSM funding. Retrieved October 11, 2015 from https://www3.ebu.ch/files/live/sites/ebu/files/Publications/EBU-Viewpoint-PSM-Funding_EN.pdf.

European Broadcasting Union. (2014). Funding of public service media 2014. Retrieved October 11, 2015 from http://www.ebu.ch/contents/publications/restricted/media-intelligence-service/ funding-of-PSM-2014.html.

Eurostat. (2015). Real GDP growth rate - volume. Retrieved January 3, 2016 from http://ec.europa. $\mathrm{eu} /$ eurostat $/ \mathrm{tgm} / \mathrm{table} . \mathrm{do}$ ?tab=table\&init=1\&language $=$ en \&pcode=tec00115\&plugin $=1$.

Freedman, D. (2008). The Politics of Media Policy. Cambridge: Polity Press.

Jastramskis, D. (2013). Žiniasklaidos paramos politika Lietuvoje [Media support policy in Lithuania]. Informacijos mokslai, 63, pp. 129-141.

Jastramskis, D. (2015). The political (in)dependence of the media in Lithuania. Kwartalnik Nauk o Mediach, 1. Retrieved October 11, 2015 from http://knm.uksw.edu.pl/the-political-independence-of-the-media-in-lithuania/.

Juska, A., Woolfson, C. (2015). Austerity, labour market segmentation and emigration: The case of Lithuania. Industrial Relations Journal, 46 (3), pp. 236-253.

Kattel, R., Raudla, R. (2013). The Baltic Republics and the Crisis of 2008-2011. Europe-Asia Studies, 65 (3), pp. 426-449.

Lange, A. (2008). Comparative analysis of the financing of the public audiovisual sector in the European Union. Strasbourg: European Audiovisual Observatory. Retrieved October 11, 2015 from http://archive.dgmic.culture.gouv.fr/IMG/pdf/Andre_Lange_Financement_secteur_public_ EN.pdf.

Meier, W.A., Trappel, J. (2015). Grappling with post-democracy: Media policy options. In: J. Trappel, J. Steemers, B. Thomass (eds.). European Media in Crisis: Values, Risks and Policies. New York: Routledge, pp. 219-230.

Nakrošis, V., Vilpišauskas, R., Kuokštis, V. (2015). Fiscal consolidation and structural reforms in Lithuania in the period 2008-2012: From grand ambitions to hectic firefighting. International Review of Administrative Sciences, 81 (3), pp. 522-540.

The Programme of the Government of the Republic of Lithuania. (2008). Seimas of the Republic of Lithuania. Resolution No XI-52 of 9 December 2008. Retrieved January 1, 2016 from https://lrv. lt/uploads/main/documents/files/EN_version/Previous_Governments/en_15_programa.pdf.

The Public Procurement Office. (2014). Viešinimo paslaugu pirkimai 2011-2013 m. I pusm. [Publicity service contracts 2011-2013]. Retrieved September 29, 2015 from http://www.vpt.lt/vpt/uploaded/Kita/Viesinimo\%20paslaugu\%20pirkimai_2011-2013\%20m.\%20I\%20pusm.pdf.

Republic of Lithuania Law Amending and Supplementing Articles 6, 7, 15 of the Law on National Radio and Television. Teisés aktu registras, 2014-01-06, Nr. 2014-00033.

Republic of Lithuania Law Amending Article 3 of the Law Amending and Supplementing Articles $6,7,15$ of the Law on National Radio and Television. Teises aktu registras, 2014-05-13, Nr. 201405355 .

Republic of Lithuania Law Amending Article 47 of the Law on the Provision of Information to the Public. Valstybès žinios, 2012-06-30, No. 76-3924.

Republic of Lithuania Law Amending Articles 3, 31, 41, 43, 46, 49, 50 and Supplementing by Article 46-1 of the Law on the Provision of Information to the Public. Teises aktu registras, 2014-12-04, Nr. 18935.

Republic of Lithuania Law on the Provision of Information to the Public. Valstybés žinios, 1996-0726, No. 71-1706.

Republic of Lithuania Law on Value Added Tax. Valstybès žinios, 2002-04-05, Nr. 35-1271. 
Republic of Lithuania Laws on Approval of the Financial Indicators of the State Budget and Municipal Budgets. Teises aktu registras, 2004-2014. Retrieved October 11, 2015 from https://www.etar.lt/portal/lt/legalActSearch.

The Republic of Lithuania Ministry of Social Security and Labour. (2015). Social insurance contributions. Retrieved October 25, 2015 from http://www.socmin.lt/en/social-insurance-1975/socialinsurance-contributions.html.

Saura, L.B., Papathanassopuolos, S. (2015). European communication and information industries in times of crisis: Continuities and transformations. In: J. Trappel, J. Steemers, B. Thomass (eds.). European Media in Crisis: Values, Risks and Policies. New York: Routledge, pp. 45-63.

Starkevičiūte, M. (2000). Pereinamo laikotarpio rezultatų Lietuvos ekonomikoje ịvertinimas [An overview of transition period results in Lithuania]. Organizaciju vadyba: sisteminiai tyrimai, 16, pp. 121-130.

The State Social Insurance Fund Board under the Ministry of Social Security and Labor of the Republic of Lithuania. (2015). Statistika. Apdraustieji. Vidutines apdraustuju pajamos [Statistics. Insured persons. Average income of insured persons]. Retrieved October 15, 2015 from http:// atvira.sodra.lt/lt-eur/index.html.

The State Tax Inspectorate under the Ministry of Finance of the Republic of Lithuania. (2015). Apie VMI. Statistika. Mokesčiu mokètojai. Gyventojai [About STI. Statistics. Tax payers. Inhabitants]. Retrieved October 12, 2015 from http://www.vmi.lt/cms/gyventojai.

Statistics Lithuania. (2015a). Official Statistics Portal. Business statistics. Services. Database of indicators. Retrieved October 25, 2015 from http://osp.stat.gov.lt/en/rodikliai44.

Statistics Lithuania. (2015b). Official Statistics Portal. Population and social statistics. Remuneration and labour costs. Average monthly earnings by sector. Retrieved October 25, 2015 from http://osp. stat.gov.lt/en/statistiniu-rodikliu-analize?portletForm Name=visualization\&hash=77bcd661aee9-4828-9809-e158baf3bf3e.

TNS LT. (2010). Metine žiniasklaidos tyrimu apžvalga $2009 \mathrm{~m}$. [Annual review of Media Surveys 2009]. Retrieved October 25, 2015 from http://www.tns.lt/lt/top/paslaugos/ziniasklaidos-auditoriju-tyrimai/metine-ziniasklaidos-tyrimu-apzvalga.

TNS LT. (2011). Metine žiniasklaidos tyrimų apžvalga $2010 \mathrm{~m}$. [Annual review of Media Surveys 2010]. Retrieved October 25, 2015 from http://www.tns.lt/lt/top/paslaugos/ziniasklaidos-auditoriju-tyrimai/metine-ziniasklaidos-tyrimu-apzvalga/.

TNS LT. (2012). Žiniasklaidos tyrimu apžvalga 2011 [Annual review of Media Surveys 2011]. Retrieved October 25, 2015 from http://www.tns.lt/data/files/Metines_apzvalgos/Ziniasklaidos\%20 tyrimu\%20apzvalga\%202011.pdf.

TNS LT. (2014a). Metinè žiniasklaidos tyrimų apžvalga 2002-2013 [Annual review of Media Surveys 2002-2013]. Retrieved October 25, 2015 from http://www.tns.lt/lt/top/paslaugos/ziniasklaidosauditoriju-tyrimai/metine-ziniasklaidos-tyrimu-apzvalga/.

TNS LT. (2014b). Annual review of Media Surveys 2013. Retrieved October 25, 2015 from http://www. tns.lt/file/repository/Ziniasklaidos\%20tyrimu\%20apzvalga\%202013\%20EN.pdf.

Veidas.lt. (2012). Kokios profesijos žada didžiausius ir mažiausius atlyginimus [What professions promise maximum and minimum remuneration]. Veidas.lt, 2012-03-21. Retrieved October 15, 2015 from http://www.veidas.lt/kokios-profesijos-zada-didziausius-ir-maziausius-atlyginimus. 